\title{
MODEL PEMBELAJARAN COOPERATIVE INTEGRATED READING AND COMPOCITION (CIRC) DALAM MENINGKATKAN HASIL BELAJAR MATA PELAJARAN AKIDAH AKHLAK
}

\author{
Rasmuin \\ UIN Maulana Malik Ibrahim Malang \\ Email: muin@uin-malang.ac.id \\ Siti Suwaibatul Islamiyah \\ UIN Maulana Malik Ibrahim Malang \\ Email: batulislamiyah16@gmail.com
}

\begin{abstract}
The purpose of this study was to determine the application of Cooperative Integrated Reading and Composition (CIRC) in improving grade 8 students learning outcomes in the subjects of the Akidah Akhlak MTs N Batu. This research is a classroom action research, which is a research that is situational, practical, and contextual based on the problems that arise in the learning activities of the Akidah Akhlak. This classroom action research was conducted in 3 cycles, namely pre cyle, cycle 1 and cycle 2 . Based on the research that has been carried out, it can be concluded that the implementation of the learning of Akidah Akhlak by applying the cooperative integrated reading and composition (CIRC) learning model shows an increase in student learning outcomes. In the pre-cycle stage the average score reached 62.25 and only 12 students or $38.70 \%$


achieved mastery learning. Then in cycle 1 by applying the cooperative integrated reading and composition (CIRC) learning model the average value increased to 84.70 and there were 18 students or $58.06 \%$ who achieved mastery learning. Furthermore, in cycle 2 the average score increased to reach 94.77 and there were 21 students or $67.74 \%$ who achieved mastery learning.

Keywords: Learning Model, Cooperative Learning, Akidah Akhlak, Learning Outcomes

\section{PENDAHUUAN}

Pendidikan bagi anak adalah suatu tumpuan bagi seseorang untuk mencapai proses pembiasaan dalam kehidupan sehari-hari, pembiasaan yang dilakukan di lingkungan keluarga atau lingkungan sekolah serta unsur-unsur yang saling berhubungan sehingga dapat mewujudkan tujuan pendidikan dengan menunjukkan hasil belajar yang memuaskan.

Dalam kehidupan bermasyarakat, berbangsa, dan bernegara tentunya terjadi perubahan dan perkembangan, hal tersebut tidak terlepas dari teknologi, ilmu pengetahuan, seni, sastra, dan budaya. Sementara itu, pendidikan sangat berperan penting dalam kemajuan ilmu pengetahuan dan teknologi. Keluarga, masyarakat, dan pemerintah bertanggung jawab dalam pendidikan. Semua orang memiliki andil dalam proses pendidikan sehingga pembahasan tentang problematika pendidikan merupakan topik yang menarik untuk diperbincangkan.

Bangsa indonesia membutuhkan seorang yang kreatif yang mampu untuk melihat peluang sekecil apapun serta mampu untuk mengubah kekurangan menjadi kelebihan. Seseorang yang kreatif akan selalu berusaha untuk mencari dan menciptakan inovasi yang tiada henti. Kemampuan kreatif manusia akan mampu membuahkan perkembangan teknologi dan informasi pada saat ini. Berbekal budi, akal, dan karsa, manusia akan mampu menciptakan berbagai macam perubahan terhadap ilmu pengetahuan serta mengaplikasikannya dalam mencari solusi terhadap problematika yang sedang dihadapi. ${ }^{1}$

Pendidikan memang sangatlah dibutuhkan oleh semua manusia. Melalui proses pendidikan yang dijalani dengan baik dan benar, manusia akan mampu menghadapi ketatnya persaingan di era modern ini. Proses pendidikan yang berjalan dengan baik dan benar sangat dibutuhkan

1 Tatag Yuli Eko Siswono, Model Pembelajaran Matematika Berbasis Pengajaran dan Pemecahan Masalah untuk. Meningkatkan Kemampuan Berpikir Kreatif, (Surabaya: UNESA University Press, 2008), hal. 1 
untuk menghadapi perkembangan zaman yang semakin pesat. Proses ini akan mampu memberikan efek yang signifikan terhadap kualitas sumber daya manusia. Menurut UU RI pendidikan adalah usaha sadar dan terencana untuk mewujudkan suasana belajar dan proses pembelajaran agar peserta didik secara aktif mengembangkan potensi dirinya untuk memilih kekuatan spiritual, keagamaan, pengendalian diri, kepribadian, kecerdasan, akhlak mulia, serta keterampilan yang diperlukan dirinya, masyarakat, bangsa, dan Negara. ${ }^{2}$

Siswa-siswa sering beranggapan bahwa mempelajari materi Akidah Akhlak itu sulit, maka guru dituntut untuk dapat memberikan inovasi terbaru dalam menerapkan model pembelajaranya sehingga dapat mempengaruhi anggapan siswa-siswi. Namun, masih sering ditemui guru masih menggunakan model pembelajaran konvensional sepert menggunakan metode ceramah sebagai metode utama dalam menyampaikan materi Akidah Akhlak.

Penggunaan model pembelajaran konvensional dalam proses pembelajaran oleh guru Akidah Akhlak di sekolah dianggap kurang mampu untuk menumbuhkan ide dan gagasan siswa baik dalam bentuk soal maupun cara mengingat berbagai peristiwa serta kurangnya siswasiswi berkesempatan untuk aktif berpartisipasi dalam proses pembelajaran, seperti bertanya, menjawab pertanyaan dan mengemukakan pendapat. Guru harus mampu memilih dan menggunakan secara tepat tipe-tipe model pembelajaran yang akan digunakannya dalam kegiatan belajar mengajar. Model pembelajaran yang tepat akan mampu untuk menghidupkan suasana kelas serta tujuan pembelajaran dapat tercapai secara optimal. Model pembelajaran yang tepat juga akan menghilangkan stigma bahwa pelajaran Akidah Akhlak itu sulit dan membosankan.

Dari beberapa studi literatur yang telah dilakukan terdapat beberapa penelitian yang berhubungan dengan penelitian ini. Penelitian tersebut antara lain yang dilakukan oleh Carollina dan Dylmoon dengan judul "The Implementation of The Cooperative Integrated Reading and Composition Technique to Increase Grade 8 Students' Active Learning in an English Class". Dalam penelitian ini peneliti mendapatkan kesimpulan bahwa penggunaan model pembelajaran CIRC mampu meningkatkan keaktifan siswa secara signifikan ${ }^{3}$. Selanjutnya penelitian kuantitatif yang dilakukan

2 Undang-undang RI Nomor 20 Tabun 2003 Tentang Sistem Pendidikan Nasional, (Jakarta: Sinar Grafika, 2009), hal. 3

3 Carollina dan Dylmoon, The Implementation of The Cooperative Integrated Reading and Composition Technique to Increase Grade 8 Students' Active Learning in an English Class, Polyglot Vol. 14 No. 2 2018, hlm.2. 
oleh Wina dengan judul "Efektivitas Penerapan Model Cooperative Integrated Reading and Composition Terhadap Pemahaman Konsep Siswa Pada Pembelajaran IPS di Sekolah Dasar". Dari uji statistic yang dilakukannya diperoleh kesimpulan bahwa penggunaan CIRC lebih efektif dibandingkan dengan pembelajaran yang menggunakan model pembelajaran konvensional. ${ }^{4}$

Selanjutnya dengan menggunakan penelitian kuantitatif pula Faisal dan Nanda menemukan bahwa CIRC eknik CIRC dapat meningkatkan konten dan organisasi tulisan siswa dalam melakukan teks recount. Selain itu, karena siswa bekerja dalam kelompok, mereka memiliki lebih banyak kesempatan untuk belajar dan berbagi ide dengan siswa lain untuk menghasilkan tulisan yang lebih baik ${ }^{5}$. Penelitian yang dilakukan oleh Kintan dan Asri juga mendapatkan kesimpulan yang sama. Dengan model pembelajaran CIRC motivasi dan hasil belajar siswa SMK N Lubuk Pakam jurusan Konstruksi Bangunan pada kompetensi dasar menerapkan spesifikasi dan karakteristik kayu terjadi peningkatan ${ }^{6}$.

Dari beberapa latar belakang di atas peneliti tertarik untuk memilih model pembelajaran CIRC (Cooperative Integrated Reading and Composition) karena mempunyai berbagai macam kelebihan. Kelebihan-kelebihan tersebut antara lain para siswa secara bebas bisa memberikan tanggapannya terhadap persoalan yang dibahas, mereka dibiasakan untuk saling bekerja sama antar siswa serta menghargai pendapat orang lain, menambah motivasi siswa untuk dapat menyelesaikan tugas secara teliti, serta dapat meningkatkan hasil belajar siswa terutama dalam mengerjakan soal yang berupa pemecahan masalah. ${ }^{7}$ Pemilihan model pembelajaran CIRC (Cooperative Integrated Reading and Composition) ini bertujuan untuk memaksimalkan proses pembelajaran sehingga siswa mampu mencapai tujuan pembelajaran dengan hasil yang maksimal pula.

\footnotetext{
${ }^{4}$ Wina Dwi Puspitasari, "Efektivitas Penerapan Model Cooperative Integrated Reading and Composition Terhadap Pemahaman Konsep Siswa Pada Pembelajaran IPS di Sekolah Dasar", Jurnal Cakrawala Pendas Vol 5 No 1 2019, hlm 1.

5 Faisal Mustafa dan Nanda Marlina, "Cooperative Integrated Reading and Composition Technique for Improving Content and Organization in Writing", SIELE Journal Vol 2 No 1 2015, hlm.1.

${ }^{6}$ Kintan Jenisa dan Asri Lubis, "Penerapan Model Pembelajaran Cooperative Integrated Reading And Composition (Circ) Untuk. Meningkatkan Motivasi Dan Hasil Belajar Konstruksi Bangunan Siswa Kelas X TGB SMK Negeri 1 Lubuk Pakam", Jurnal Education Building Vol 2 No 1 2016, hlm.1.

7 Ariyadi Ahsan, Model Pembelajaran Kooperatif, dalam http://modelpembelajarankooperatif.blogspot.com/2012/08/circ.html, diakses 28 September 2019.
} 


\section{KAJIAN TEORI}

Cooperative Integrated Reading and Composition (CIRC)

Cooperative Integrated Reading and Composition (CIRC) adalah kegiatan pembelajaran yang dilakukan secara menyeluruh melalui kegiatan membaca, menulis dan peserta didik dilatih untuk dapat melibatkan diri dalam kegiatan kerjasama kelompok dan meningkatkan kesuksesan individu peserta yang menjadi tolak ukur kesuksesan kelompok ${ }^{8}$. Sebagai seorang pendidik, guru diharuskan untuk selalu meningkatkan kualitas pembelajaran melalui peggunaan berbagai model pembelajaran yang cocok dalam proses pembelajaran. Model pembelajaran digunakan sebagai upaya meningkatkan prestasi peserta didik. Seorang pendidik mempunyai kebebasan untuk memilih model pembelajaran yang akan digunakan dengan menyesuaikan materi yang akan disampaikan kepada peserta didik, kondisi peserta didik, dan kondisi kelas. Cooperative Integrated Reading and Composition (CIRC) adalah salah satu model pembelajaran yang menjadi alternatif pada proses pembelajaran.

Pembelajaran kooperatif menjadi sangat penting dalam praktik pendidikan atau proses pembelajaran. Model pembelajaran ini diklaim mampu meningkatkan hasil belajar peserta didik, mempererat hubungan antar peserta didik dalam suatu kelompok dan menanamkan sikap toleransi antar peserta didik. Cooperative Integrated Reading and Composition (CIRC) merupakan program pembelajaran yang komprehensif melalui kegiatan membaca, menulis, serta membiasakan siswa untuk melibatkan diri dalam kerjasama kelompok yang dapat diterapkan pada proses pembelajaran tingkatan sekolah dasar atau juga pada tingkatan sekolah menengah.

Beberapa langkah yang harus dilakukan dalam penerapan model pembelajaran Cooperative Integrated Reading and Composition (CIRC) pada proses pembelajaran ialah sebagai berikut:

a. Guru membagi siswa kedalam beberapa kelompok yang beranggotakan 4-5 orang secara heterogen berdasarkan instruksi guru.

b. Setiap kelompok mendapatkan wacana yang sesuai dengan topik dan materi yang telah disiapkan oleh guru.

c. Perwakilan kelompok bertugas membacakan wacana yang telah dibagikan secara bergantian dan menemukan ide pokok serta anggota kelompok yang lain bertugas menuliskan ide pokok dalam selembar kertas.

\footnotetext{
8 Agus Krisno Budiyanto, Model Pembelajaran dalam Student Centered Learning, (Malang: Universitas Muhammadiyah Malang Press, 2016), hal.37.
} 
d. Guru memperhatikan aktifitas siswa-siswi pada setiap individu dan kelompok meliputi; keaktifan siswa-siswi terhadap situasi kelompok, perhatian siswa-siswi dalam mendengarkan anggota kelompok saat membacakan wacana, membantu memberikan pemahaman kepada anggota yang mengalami kesulitan dalam memahami materi yang dibacakan, kemampuan siswa-siswi dalam mengemukakan pendapat atau memberikan sanggahan serta tanggapan mengenai materi dalam wacana yang dibagikan, keberanian dan kecakapan siswa-siswi dalam mempresentasikan hasil diskusi kelompoknya di depan kelas, membuat kesimpulan sendiri, kemampuan siswa dalam mengerjakan soal dengan baik dan benar.

e. Dengan bimbingan guru, siswa-siswi membuat kesimpulan terkait meteri yang telah didiskusikan.

f. Sebagai upaya mengetahui tingkat kepahaman siswa-siswi terhadap materi yang telah disampaikan dan didiskusikan bersama melalui model pembelajaran Cooperative Integrated Reading and Composition (CIRC), guru memberikan evaluasi berupa latihan soal kepada setiap siswa-siswi pada sesi akhir pembelajaran.

\section{Hasil Belajar}

Hamalik dalam Affandi menyatakan bahwa seseorang akan mengalami perubahan tingkah laku sebagai akibat dari proses kegiatan belajar mengajar?. Berkat adanya proses pembelajaran manusia akan menjadi tahu dari ketidak tahuan, berubah menjadi mampu dari ketidak mampuan serta yang sebelumnya belum mengerti berubah menjadi mengerti akan suatu hal. Beberapa perubahan diatas dapat diukur dari hasil belajar siswa-siswi yang tampak dari beberapa aspek diantaranya: pengetahuan, keterampilan, kebiasaan, emosional, hubungan sosial, tingkah laku, dan sikap. Seseorang akan mengalami perubahan dalam beberapa aspek tingkah laku sebagai pengaruh hasi belajar seseorang yang telah melalui perbuatan belajar.

Sanjaya mengemukakan pendapat lain dari sebelumnya bahwa tingkah laku merupakan suatu hasil belajar yang kemudian kompetensi dan kemampuan dirumuskan menjadi titik ukur yang dapat ditampilkan melalui performance siswa-siswi saat di proses pembelajaran atau diluar proses pembelajaran. Beberapa istilah sebagai indikator hasil belajar untuk dapat mengukur tingkah laku siswa-siswi hasil belajar adalah

9 Muhammad Afandi.Dkk, Model dan Metode Pembelajaran di Sekolah,(Semarang : UNISSULA Press,2013), Hlm. 4-6. 
mengidentifikasi (identify), menyebutkan (name), menyusun (construct), menjelaskan (describe), mengatur (order), dan membedakan (different) ${ }^{10}$.

Hasil belajar menurut Bloom dan Purwanto (2007: 45) hasil belajar digolongkan menjadi tiga ranah yang harus diperhatikan dalam proses pembelajaran. (1) Ranah kognitif, hasil belajar yang mencakup ingatan pengetahuan, kemampuan intelektual, dan pemahaman materi. (2) Ranah afektif, penilaian sikap, perilaku, perasaan, nilai-nilai dan minat menjadi cakupan hasil belajar siswa-siswi. dan (3) Ranah psikomotorik, hasil belajar yang mencakup keterampilan fisik dan kemampuan psikis sebagai penunjangnya.

Berdasarkan pendapat dari beberapa ahli dapat disimpulkan bahwa hasil belajar adalah perubahan yang terjadi pada kemampuan peserta didik meliputi kemampuan kognitif, kemampuan afektif dan kemampuan psikomotor. Perubahan itu dapat diartikan adanya perubahan dan perkembangan yang lebih baik dibandingkan sebelumnya. Dari proses pembelajaran diharapkan adanya perubahan yang sesuai dengan tahap operasional kongrit pekembangan peserta didik.

\section{HASIL DAN PEMBAHASAN}

Pendidikan Akidah Akhlak memiliki peran yang sangat urgen dalam kehidupan umat Islam. Akidah dan akhlak inilah yang menentukan kualitas diri dari seorang muslim. Akidah merupakan kepercayaan yang terbebas dari perasaan bimbang dan ragu dimana hati membenarkannya ${ }^{11}$. Sedangkan Akhlak adalah wujud realisasi dan aktualisasi diri dari akidah seseorang. Ia merupakan sifat dasar manusia yang tertanam sejak lahir dalam dirinya ${ }^{12}$.

Berdasarkan data yang diperoleh dari proses pembelajaran dengan menerapkan model pembelajaran Cooperative Integrated Reading and Compocition (CIRC) pada mata pelajaran Akidah akhlak di MTs Negeri Batu melalui penelitian tindakan kelas dan dilaksanakan di kelas VIII-A yang dilakukan sebanyak 3 siklus (pra siklus, siklus 1, dan siklus 2). Maka dapat menghasilkan data dan selanjutnya dapat di analisa.

Penerapan pembelajaran model Cooperative Integrated Reading and Composition (CIRC) pada pra siklus, siklus 1 dan siklus 2 telah

\footnotetext{
10 Wina Sanjaya, Strategi Pembelajaran Berorientasi Standar Pendidikan, (Jakarta: Kencana, 2010), hlm. 87.

${ }^{11}$ Nursiyam, Pengaruh Sistem Pembelajaran Kampus Terhadap Penguatan Akidah dan Akblak Mahasiswa IAIN Samarinda, Syamil 3 no 2 (1 des 2015; 342)

12 Dedi Wahyudi, Pengantar Akidah Akblak dan Pembelajarannya, (Yogyakarta: Lintang, 2017), hlm.2.
} 
dilaksanakan dengan sangat baik. Hal ini dapat dipastikan melalui data rekapitulasi hasil observasi sebagai beikut :

Tabel 1: Rekapitulasi hasil observasi model pembelajaran model Cooperative Integrated Reading and Composition (CIRC)

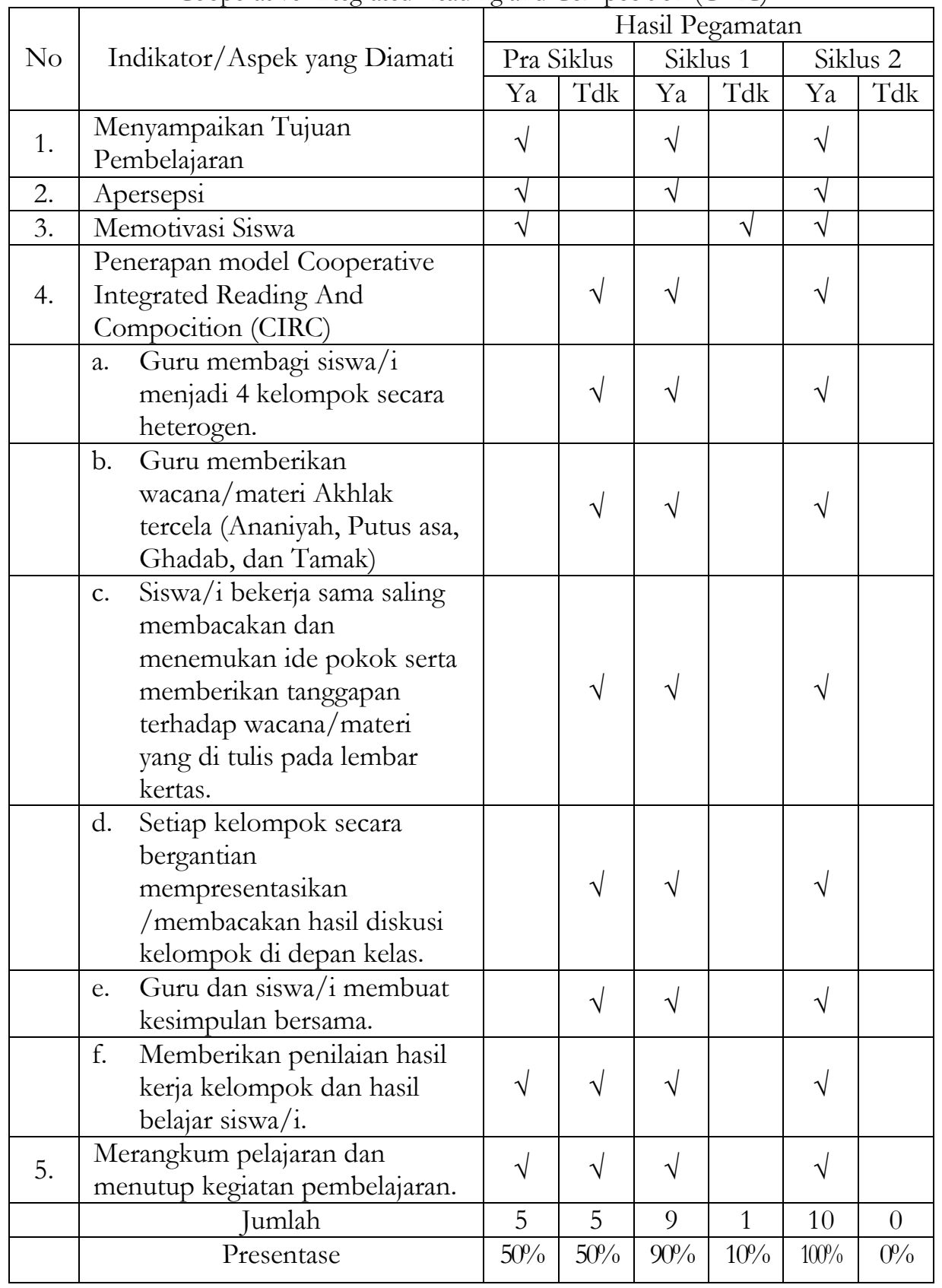

Sumber: Data Olahan Observasi 
Penerapan model Cooperative Integrated Reading And Compocition (CIRC) membberikan pengaruh terhadap hasil belajar siswa,-siswi secara signifikan terhadap yang dapat dilihat melalui tabel hasil belajar siswasiswi, sebagai berikut :

Tabel 2: Rekapitulasi hasil belajar siswa

\begin{tabular}{|c|c|c|c|c|c|c|}
\hline \multirow{2}{*}{$\begin{array}{c}\text { No Urut } \\
\text { Siswa }\end{array}$} & \multicolumn{2}{|c|}{ Pra Siklus } & \multicolumn{2}{|c|}{ Siklus 1} & \multicolumn{2}{|c|}{ Siklus 2} \\
\hline & Nilai & Ket & Nilai & Ket & Nilai & Ket \\
\hline 1 & 60 & $\mathrm{TT}$ & 80 & TT & 95 & $\mathrm{~T}$ \\
\hline 2 & 55 & $\mathrm{TT}$ & 75 & $\mathrm{TT}$ & 95 & $\mathrm{~T}$ \\
\hline 3 & 60 & $\mathrm{TT}$ & 85 & $\mathrm{~T}$ & 95 & $\mathrm{~T}$ \\
\hline 4 & 55 & $\mathrm{TT}$ & 85 & $\mathrm{~T}$ & 97 & $\mathrm{~T}$ \\
\hline 5 & 60 & $\mathrm{TT}$ & 90 & $\mathrm{~T}$ & 100 & $\mathrm{~T}$ \\
\hline 6 & 80 & $\mathrm{~T}$ & 80 & $\mathrm{~T}$ & 100 & $\mathrm{~T}$ \\
\hline 7 & 60 & $\mathrm{TT}$ & 75 & $\mathrm{TT}$ & 86 & TT \\
\hline 8 & 55 & $\mathrm{TT}$ & 80 & $\mathrm{TT}$ & 91 & TT \\
\hline 9 & 70 & $\mathrm{~T}$ & 95 & $\mathrm{~T}$ & 100 & $\mathrm{~T}$ \\
\hline 10 & 65 & $\mathrm{~T}$ & 75 & TT & 86 & TT \\
\hline 11 & 60 & $\mathrm{TT}$ & 85 & $\mathrm{~T}$ & 100 & $\mathrm{~T}$ \\
\hline 12 & 65 & $\mathrm{~T}$ & 85 & $\mathrm{~T}$ & 100 & $\mathrm{~T}$ \\
\hline 13 & 55 & $\mathrm{TT}$ & 85 & $\mathrm{~T}$ & 100 & $\mathrm{~T}$ \\
\hline 14 & 65 & $\mathrm{~T}$ & 97 & $\mathrm{~T}$ & 85 & TT \\
\hline 15 & 60 & $\mathrm{TT}$ & 80 & $\mathrm{TT}$ & 83 & TT \\
\hline 16 & 70 & $\mathrm{~T}$ & 85 & $\mathrm{~T}$ & 97 & $\mathrm{~T}$ \\
\hline 17 & 70 & $\mathrm{~T}$ & 97 & $\mathrm{~T}$ & 100 & $\mathrm{~T}$ \\
\hline 18 & 55 & $\mathrm{TT}$ & 85 & $\mathrm{~T}$ & 90 & TT \\
\hline 19 & 70 & $\mathrm{~T}$ & 80 & TT & 100 & $\mathrm{~T}$ \\
\hline 20 & 60 & $\mathrm{TT}$ & 100 & $\mathrm{~T}$ & 80 & TT \\
\hline 21 & 55 & $\mathrm{TT}$ & 75 & TT & 93 & TT \\
\hline 22 & 60 & $\mathrm{TT}$ & 80 & TT & 88 & TT \\
\hline 23 & 60 & $\mathrm{TT}$ & 75 & TT & 97 & $\mathrm{~T}$ \\
\hline 24 & 60 & $\mathrm{TT}$ & 80 & $\mathrm{TT}$ & 97 & $\mathrm{~T}$ \\
\hline 25 & 70 & $\mathrm{~T}$ & 80 & TT & 100 & $\mathrm{~T}$ \\
\hline 26 & 65 & $\mathrm{~T}$ & 95 & $\mathrm{~T}$ & 95 & $\mathrm{~T}$ \\
\hline 27 & 60 & $\mathrm{TT}$ & 100 & $\mathrm{~T}$ & 100 & $\mathrm{~T}$ \\
\hline 28 & 65 & $\mathrm{TT}$ & 90 & $\mathrm{~T}$ & 100 & $\mathrm{~T}$ \\
\hline 29 & 70 & $\mathrm{~T}$ & 97 & $\mathrm{~T}$ & 100 & $\mathrm{~T}$ \\
\hline 30 & 70 & $\mathrm{~T}$ & 80 & $\mathrm{~T}$ & 93 & TT \\
\hline
\end{tabular}




\begin{tabular}{|c|c|c|c|c|c|c|}
31 & 45 & TT & 75 & TT & 95 & T \\
\hline JUMLAH & 1930 & & 2626 & & 2938 & \\
\hline RATA2 & 62,25 & & 84,7 & & 94,77 & \\
\hline T & $38,70 \%$ & & $58,06 \%$ & & $67,74 \%$ & \\
\hline TT & $61,29 \%$ & & $41,93 \%$ & & $32,25 \%$ & \\
\hline
\end{tabular}

Berdasarkan data rekapitulasi hasil penelitian pada table diatas dapat dijelaskan bahwa perlakuan model pembelajaran pada saat pra siklus nilai rata-rata yang diperoleh siswa hanya sebesar 62,25. Pada siklus 1 pembelajaran Akidah Akhlak yang sudah menerapkan pembelajaran cooperative integrated reading and compocition (CIRC) nilai rata-rata kelas mengalami peningkatan menjadi 84,70. Pada siklus 2 kembali terjadi peningkatan rata-rata nilai mencapai 94,77. Persentase rata-rata nilai hasil belajar siswa terlihat secara jelas pada grafik di bawah ini:

Gambar 1: Grafik Rata-rata hasil belajar siswa

\section{Rata-rata Nilai Hasil Belajar Siswa \\ Mata Pelajaran Akidah AKhlak}

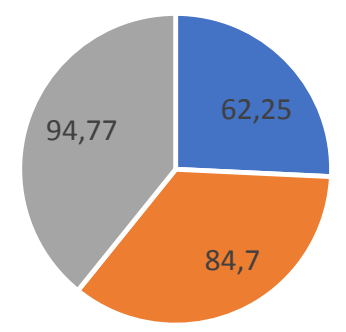

- Pra Siklus = Siklus 1 - Siklus 2

Menurut rekapitulasi hasil penelitian yang tertulis pada tabel 2 di atas, bisa diketahui bahwa ketuntasan belajar siswa yang dilakukan pada saat sebelum tindakan atau pra siklus pada mata pelajaran Akidah Akhlak masih sangat rendah. Tercatat hanya 38,70\% atau sebanyak 12 orang siswa yang mampu mencapai standar kriteria ketuntasan minimal (KKM) yang ditentukam oleh guru mata pelajaran sebesar 75 . Selanjutnya pada siklus 1 yang telah menggunakan model pembelajaran cooperative integrated reading and compocition (CIRC) terjadi adanya peningkataan. Siswa yang telah mampu memenuhi kriteria ketuntasan minimal sebanyak 18 siswa atau 58,06\%. Kemudian pada siklus yang kedua hasil 
belajar siswa Kembali mengalami peningkatan. Pada siklus dua ini sebanyak 21 siswa dari total 31 siswa yang telah mampu memenuhi KKM. Atau dengan kata lain siswa yang telah memenuhi standar minimal KKM sudah mencapai $67,74 \%$.

Gambar 1: Grafik ketuntasan belajar siswa

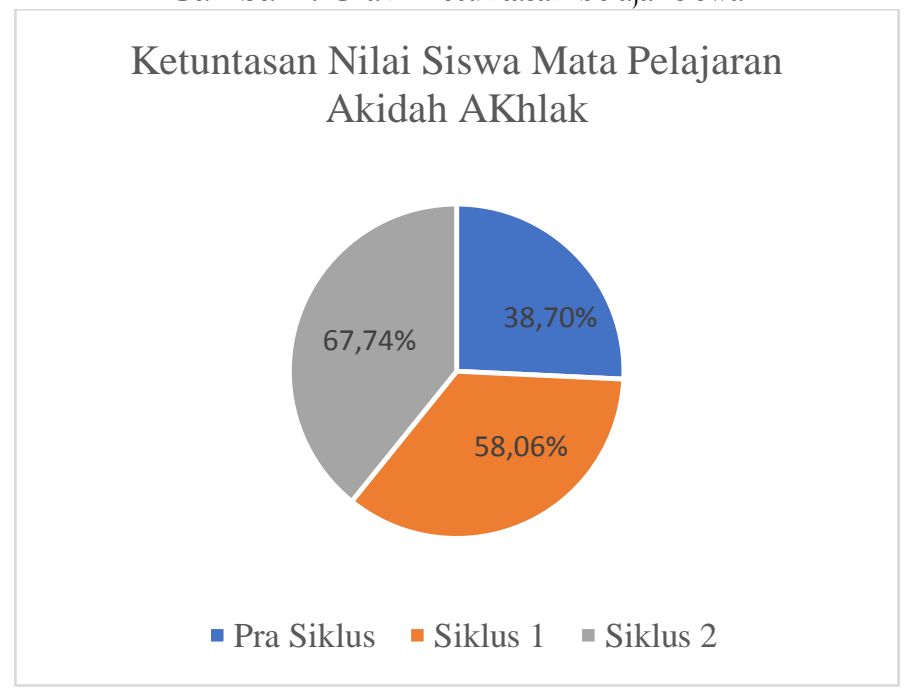

Dengan hasil tersebut di atas, menunjukkan bahwa penerapan model pembelajaran cooperative integrated reading and compocition (CIRC) mampu mempengaruhi peningkatan hasil belajar siswa pada mata pelajaran Akidah Akhlak di MTs. Negeri Batu.

\section{KESIMPULAN}

Pelaksanaan pembelajaran Akidah Akhlak dengan menerapkan model pembelajaran cooperative integrated reading and compocition (CIRC) dilaksanakan dengan beberapa tahapan yaitu; Pra pembelajaran, Kegiatan awal, kegiatan inti dan Penutup.

Pembelajaran Akidah Akhlak yang telah dilakukan dengan menerapkan model pembelajaran Cooperative Integrated Reading and Compocition (CIRC) dikelas VIII A MTs. Negeri Batu mampu meningkatan hasil belajar siswa. Hal ini dapat dibuktikan berdasarkan hasil penelitian dimana pada saat pembelajaran pra siklus nilai rata-rata siswa hanya mencapai 62,25. Hanya 12 orang siswa atau 38,70\% saja yang mencapai ketuntasan belajar. Selanjutnya pada siklus 1 dengan menerapkan model pembelajaran Cooperative Integrated Reading and Compocition (CIRC) nilai rata-rata siswa mengalami peningkatan mencapai 84,70. Pada siklus ini terdapat 18 siswa atau 58,06\% yang mencapai 
ketuntasan belajar. Kemudian pada siklus 2 kembali terjadi peningkatan rata-rata nilai yang mencapai 94,77. Terdapat 21 siswa atau 67,74\% yang mencapai ketuntasan belajar.

\section{DAFTAR PUSTAKA}

Afandi, Muhammad Dkk. 2013. Model dan Metode Pembelajaran di Sekolah. Semarang: UNISSULA Press.

Ahsan, Ariyadi. 2012. Model Pembelajaran Kooperatif, dalam http://modelpembelajarankooperatif.blogspot.com/2012/08/cir c.html, diakses 28 September 2019.

Budiyanto, Agus Krisno. 2016. Model Pembelajaran dalam Student Centered Learning. Malang: Universitas Muhammadiyah Malang Press.Siswono, Tatag Y.E. 2008. Model Pembelajaran Matematika Berbasis Pengajaran dan Pemecahan Masalah untuk Meningkatkan Kemampuan Berpikir Kreatif. Surabaya: UNESA University Press.

Jenisa, Kintan dan Asri Lubis. 2016. "Penerapan Model Pembelajaran Cooperative Integrated Reading And Composition (Circ) Untuk Meningkatkan Motivasi Dan Hasil Belajar Konstruksi Bangunan Siswa Kelas X TGB SMK Negeri 1 Lubuk Pakam", Jurnal Education Building Vol 2 No 1.

Kemendiknas. 2009. Undang-undang RI Nomor 20 Tahun 2003 Tentang Sistem Pendidikan Nasional. Jakarta: Sinar Grafika.

Mustafa, Faisal dan Nanda Marlina. 2015. "Cooperative Integrated Reading and Composition Technique for Improving Content and Organization in Writing", SIELE Journal Vol 2 No 1.

Nursiyam. 2015. "Pengaruh Sistem Pembelajaran Kampus Terhadap Penguatan Akidah dan Akhlak Mahasiswa IAIN Samarinda". Syamil Vol 3 No 2.

Puspitasari, Carollina A. dan Dylmoon H. 2018. "The Implementation of

The Cooperative Integrated Reading and Composition Technique to Increase Grade 8 Students' Active Learning in an English Class". Polyglot Vol. 14 No. 2.

Puspitasari, Wina Dwi. 2019. "Efektivitas Penerapan Model Cooperative Integrated Reading and Composition Terhadap Pemahaman Konsep Siswa Pada Pembelajaran IPS di Sekolah Dasar". Jurnal Cakrawala Pendas Vol 5 No 1.

Sanjaya, Wina. 2010. Strategi Pembelajaran Berorientasi Standar Pendidikan. Jakarta: Kencana.

Wahyudi, Dedi. 2017. Pengantar Akidah Akblak dan Pembelajarannya. Yogyakarta: Lintang. 